\title{
MEDIA PEMBELAJARAN INTERAKTIF TERHADAP GWK CUTURE PARK MENGGUNAKAN TEKNOLOGI AUGMENTED REALITY
}

\author{
Usman Nurhasan $^{1}$, Arief Prasetyo², Efita Tria Wardani ${ }^{3}$ \\ 1,2,3 Teknologi Informasi, Teknik Informatika, Politeknik Negeri Malang \\ ${ }^{1}$ usmannurhasan@polinema.ac.id, ${ }^{2}$ arief.prasetyo@polinema.ac.id, ${ }^{3}$ efitatria@gmail.com
}

\begin{abstract}
Abstrak
Garuda Wisnu Kencana Culture Park Bali merupakan salah satu tempat wisata di Bali yang saat ini menjadi tempat wisata non pantai favorit. Di dalamnya terdapat sejarah mengenai kebudayaan Bali dan sejarah patung GWK itu sendiri. Namun belum banyak yang mengetahui akan sejarah tersebut. Salah satu hal menyebabkan ketidaktahuan orang akan sejarah ini adalah belum adanya suatu perangkat yang memadai. Maka dibuatkannya media pembelajaran untuk memudahkan mempelajari sejarah GWK. Aplikasi ini menerapkan teknologi Augmented Reality dan game kuis. Aplikasi ini akan dirancang menggunakan metode Simultaneous Markerless dengan library Vuforia SDK untuk pendeteksian gambar agar tampilan visual menjadi lebih menarik. Dan juga menerapkan metode Fisher Yates Shuffle untuk randomisasi soal pada kuis. Teknologi ini akan diimplementasikan pada perangkat smartphone berbasis Android. Hasil akhir yang diharapkan agar dapat menarik minat masyarakat untuk mempelajari budaya Indonesia khususnya budaya Bali dan sejarah patung GWK. Berdasarkan hasil uji coba yang dilakukan, dapat disimpulkan bahwa aplikasi ini berjalan sesuai tujuannya, dan dapat dinyatakan menarik minat belajar siswa dengan hasil presentase $86,3 \%$, sehingga didapatkan hasil responden sangat tertarik denan aplikasi yang dibuat.
\end{abstract}

Kata kunci : Augmented Reality, GWK, Vuforia SDK, Fisher Yates Shuffle, Smartphone, Android.

\section{Pendahuluan}

Garuda Wisnu Kencana (GWK) merupakan salah satu tempat wisata di Bali yang saat ini menjadi tempat wisata non pantai favorit. Keberadaan patung Dewa Wisnu serta patung Garuda di dalam GWK Culture Park Bali saat ini telah menjadi magnet bagi wisatawan dari berbagai daerah maupun negara untuk datang ke Bali.

Berbagai venue pertunjukan dengan pemandangan tebing kapur di GWK Cultural Park ini diantaranya adalah Museum Garuda Wisnu Kencana, Plaza Wisnu (tempat patung badan Dewa Wisnu berada), Garuda Plaza (tempat patung Garuda berada), Plaza Kura - Kura, Lotus Pond, Indraloka, Tirtha Agung (tempat tangan Dewa Wisnu berada), Amphitheater serta Street Theather dan masih banyak venue lainnya. Memasuki ke dalam museum Garuda Wisnu Kencana, pengunjung disuguhi foto - foto perjalanan pembangunan Garuda Wisnu Kencana Culture Park.

Saat ini penyampaian informasi kepada pengunjung Garuda Wisnu Kencana Culture Park masih berupa teks atau tulisan maka dari itu informasi yang di terima masih belum tersampaikan dengan baik. Melihat permasalahan ini, pentingnya dibuat sebuah perangkat pembelajaran tentang informasi yang terdapat pada Garuda Wisnu Kencana Culture Park yang dapat diimplementasikan secara portable, sehingga pengunjung lebih tertarik dan mudah untuk mendapatkan informasi.
Dengan kemajuan Teknologi Informasi (TI) saat ini memungkinkan penulis untuk mengembangkan sebuah aplikasi interkatif. Pengguna gadget seperti smartphone membuat pembelajaran dapat dilakukan dari mana saja dan kapan saja. Ditambah dengan kemajuan dibidang perangkat lunak, seperti teknologi Augmented Reality, memungkinkan kita dapat menjelajahi sebuah objek dalam bentuk 3 Dimensi (3D).

Untuk melihat apakah informasi tersampaikan dengan baik ke pengunjung melalui Augmented Reality, penulis memberikan sesi game, yaitu game kuis dimana game kuis berupa soal berpilihan ganda.

Metode selanjutnya yang di pakai oleh penulis adalah Fisher-Yates Shuffle sebagai sebuah Kecerdasan Buatan (Artificial intelligence) yang membantu system untuk melakukan pengacakan soal pada sesi game kuis sehingga soal akan berbeda dan bisa dihasilkan tanpa pengulangan dan duplikasi. Kuis ini berisi beberapa soal yang akan di batasi oleh waktu pengerjaannya. Soal yang digunakan oleh penulis sesuai dengan informasi yang ditampilkan pada learning Augmented Reality sebelumnya. Dengan memadukan antara Konsep Augmented Reality dan metode Fisher-Yates Shuffle, penulis berharap informasi yang di dapatkan dapat maksimal. 


\section{Tinjauan Pustaka}

\subsection{Penelitian Terdahulu}

Ir. Edson Yahuda Putra, M.Kom, dan Andria Kusuma Wahyudi, S.Kom, M.Eng (2015) [2] dengan judul "Perancangan Perangkat Visualisasi Interaktif Situs Warisan Budaya Indonesia Menggunakan Teknologi Augmented Reality dengan Metode Simultaneous Markerless Based". Mereka membuat penelitian mengenai perangkat visualisasi interaktif situs warisan budaya Indonesia menggunakan teknologi Augmented Reality dengan metode Simultaneous Markerless Based, perangkat ini diharapkan dapat diimplementasikan di berbagai museum di seluruh Indonesia.

Ekojono, dkk (2017) [3] dengan judul "Penerapan Algoritma Fisher-Yates Shuffle Pada Pengacakan Soal Game Aritmatika". Penelitian ini dipilih soal yang mudah dikerjakan sehingga semua orang yang telah belajar berhitung/aritmatika bisa mengerjakan, hanya saja ada batasan waktu. Pengacakan soal menggunakan metode algoritma Fisher-Yates Shuffle berhasil diterapkan didalam game aritamatika sebagai pengacak soal dan jawaban yang akan muncul dalam setiap permainan dan keluarnya soal tidak berulang.

\subsection{Augmented Reality}

Augmented reality adalah teknologi yang menggabungkan benda maya dua dimensi dan ataupun tiga dimensi ke dalam sebuah lingkungan nyata tiga dimensi lalu memproyeksikan bendabenda maya tersebut dalam waktu nyata. Selain menambahkan benda maya dalam lingkungan nyata, augmented reality juga berpotensi menghilangkan benda-benda yang sudah ada. Menambah sebuah lapisan gambar maya dimungkinkan untuk menghilangkan atau menyembunyikan lingkungan nyata dari pandangan pengguna.

\section{a. Markerless}

Markerless marker merupakan sebuah metode pelacakan dimana AR menggunakan objek di dunia nyata sebagai marker. AR dengan teknik markerless ini menggunakan teknik pelacakan secara alami (nature feature). Teknik ini menggunakan prinsip deteksi tepi, deteksi sudut dan tekstur dari gambar atau objek. Deteksi sudut merupakan tahapan penting dalam pelacakan secara alami, misalnya metode Simultaneous Localization and Mapping (SLAM), pencocokan dan pengenalan gambar. Dibutukan kekuatan pelacakan untuk melakukan deteksi terhadap titik - titik atau fitur - fitur dari gambar ditemukan dalam real-time frame-rate application [1].

\subsection{Augmented Reality}

Fisher-Yates Shuffle digunakan untuk mengubah urutan masukan yang diberikan secara acak. Permutasi yang dihasilkan oleh algoritma ini muncul dengan probabilitas yang sama. Namun dalam pengembangan aplikasi ini algoritma ini diterapkan dengan menggunakan metode modern. Metode modern dipilih karena metode ini memang khusus digunakan untuk pengacakan dengan sistem komputerisasi, dikarenakan hasil pengacakan bisa lebih variatif [3].

Berikut adalah metode modern pada Tabel 1 yang digunakan untuk menghasilkan suatu permutasi acak untuk angka 1 sampai $\mathrm{N}$ sebagai berikut :

1. Tuliskan angka dari 1 sampai $\mathrm{N}$.

2. Pilih sebuah angka acak $\mathrm{K}$ diantara 1 sampai dengan jumlah angka yang belum dicoret.

3. Dihitung dari bawah, coret angka $\mathrm{K}$ yang belum dicoret, dan tuliskan angka tersebut di lain tempat.

4. Ulangi langkah 2 dan langkah 3 sampai semua angka sudah tercoret.

5. Urutan angka yang dituliskan pada langkah 3 adalah permutasi acak dari angka awal.

Tabel 1. Pengerjaan Algoritma Fisher-Yates Shuffle

\begin{tabular}{cccl}
\hline Range (M) & Roll (N) & Scratch & Result \\
& & 12345 & \\
$1-5$ & 3 & 1254 & 3 \\
$1-4$ & 1 & 425 & 31 \\
$1-3$ & 2 & 45 & 312 \\
$1-2$ & 2 & 4 & 3125 \\
\hline \multicolumn{5}{c}{ Hasil Pengacakan } & 43125 \\
\hline
\end{tabular}

Tabel 1 menjelaskan proses operasi algoritma Fisher-Yates Shuffle, pertama menentukan nilai selanjutnya angka acak dipilih dan tukar posisi dengan angka terakhir sampai ke n.

\section{Metode Peneltian}

Metode yang akan digunakan dalam Pembuatan Media Pembelajaran Interaktif Terhadap Garuda Wisnu Kencana Culture Park Menggunakan Teknologi Augmented Reality adalah System Development Life Cycle (SDLC).

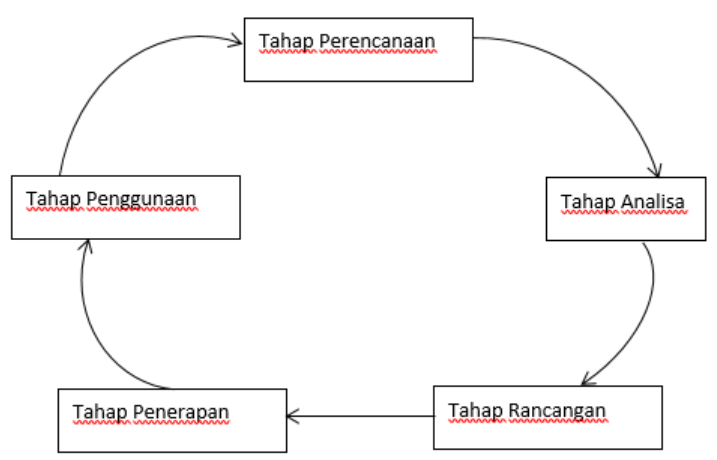

Gambar 1. System Development Lifle Cycle (SDLC) 


\subsection{Rancangan Penelitian}

Dalam membantu penyusunan penelitian ini, struktur kerja yang akan diterapkan pada sistem ini menggunakan konsep dan alur dari Software Development Life Cycle yang akan dijelaskan tahapannya secara berurutan.

\section{a. Tahap Perencanaan}

Merupakan tahap awal dari pembuatan sistem, tahap ini bertujuan untuk mengidentifikasi dan memprioritaskan apa yang akan dibuat, saran-saran yang akan dicapai, jangka waktu pelaksanaan. Tahap perencanaan menjadi penting karena permasalahan didefinisikan dan diidentifikasikan sencara rinci. Dalam kasus ini penulis menemukan beberapa masalah yaitu tidak mudahnya penyampaian informasi mengenai situs bersejarah yang berada di Garuda Wisnu Kencana Culture Park. Berdasarkan masalah tersebut terdapa salah satu tujuan dari dibangunnya aplikasi ini adalah untuk memudahkan pengunjung mendapatkan informasi dan mengukur tingkat kepahaman pengunjung menggunakan media kuis.

\section{b. Tahap Analisa}

Tahap Analisa adalah penelitian atas sistem yang telah ada dengan tujuan untuk merancang sistem baru atau memperbaharui system yang sudah ada. Pada tahap ini yang akan dilakukan yaitu menganalisis berdasarkan studi literatur untuk mendapatkan pemahaman mengenai objek virtual agar menyerupai gerak obyek nyata yang di terapkan melalui penggunaan augmented reality dan pengumpulan data yang diperlukan.

\section{c. Tahap Perancangan}

Pada tahap ini dilakukan penentuan proses dan data yang diperlukan oleh sistem baru. Jika sistem ini berbasis komputer, rancangan dapat menyertakan spesifikasi jenis peralatan yang akan digunakan. Pada tahap ini juga dilakukan membuat pemodelan proses, membuat pemodelan data, dan membuat desain tampilan antar muka (interface).

\section{d. Tahap Penerapan}

Dalam proses tahap ini yaitu tahapan yang mengacu pada perancangan. Pada proses implementasi ini analisis dan perancangan akan diimplementasikan. Proses tahapan ini menggunakan tool Unity 3D dan Vuforia untuk mendapatkan proses augmented reality. Pada tahapan yang paling akhir akan dilakukan proses implementasi pada smartphone dengan sistem operasi Android berdasarkan perancangan yang diproses sebelumnya.


yaitu:

1) Menggunakan Sistem
Pemakai menggunakan sistem untuk mencapai tujuan yang diidentifikasikan pada tahap perencanaan.

2) Memelihara Sistem

- Untuk membenarkan kesalahan atau kelemahan sistem yang tidak terdeteksi pada saat pengujian.

- Untuk membuat sistem up to date

- Untuk meningkatkan kemampuan sistem

\section{Hasil}

Implementasi system setelah selesai melakukan perancangan - perancangan sebelumnya. Implementasi pada aplikasi Media Pembelajaran Interaktif Terhadap GWK Culture Park Menggunakan Teknologi Augmented Reality ini menggunakan software Unity 2018.2 sebagai engine dan visual Studio 2017 sebagai Engine untuk membual program dengan bahasa $\mathrm{C \#}$.

\subsection{Hasil Pengujian Implementasi Fisher-Yates Shuffle pada Game}

Data Awal sebelum dilakukan pengacakan menggunakan metode fisher yates, data awal merupakan array string dengan panjang array 20 berisikan soal yang sudah di masukkan dalam array. Sebelum dilakukan pengacakan, posisi huruf masih berurutan.

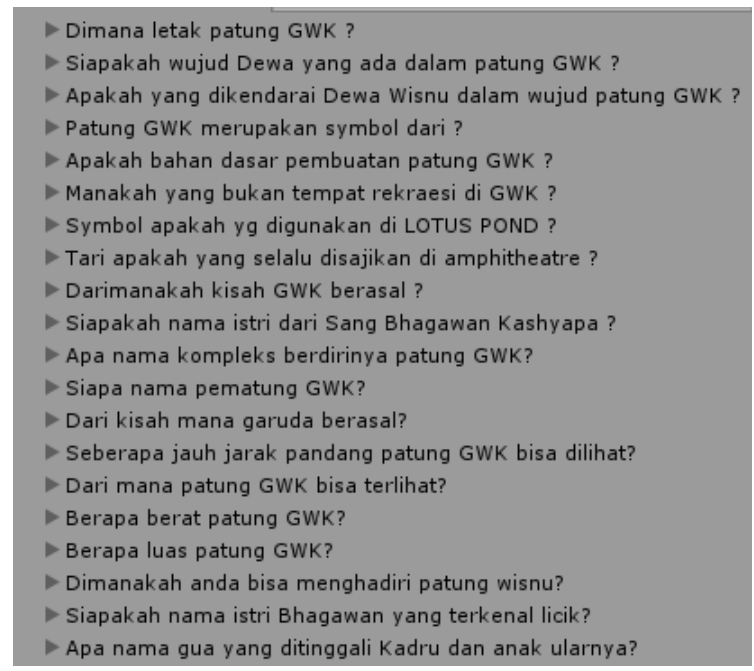

Gambar 2. Data Awal Sebelum Fisher-Yates Shuffle diimplementasikan

Proses pengacakan menggunakan metode fisher yates adalah dengan memilih index secara random, kemudian ditukar dengan index atau elemen terakhir, kemudian index terakhir di geser, misal index terakhir 19, setelah elemen terakhir ditukar, index terakhir dikurangi dengan 1 menjadi 18 , sehingga index terakhir 19 sudah tidak akan berubah lagi dan berlanjut ke index 18 hingga perulangan akan 
berhenti hingga elemen terakhir adalah 1. Seperti gambar dibawah ini :

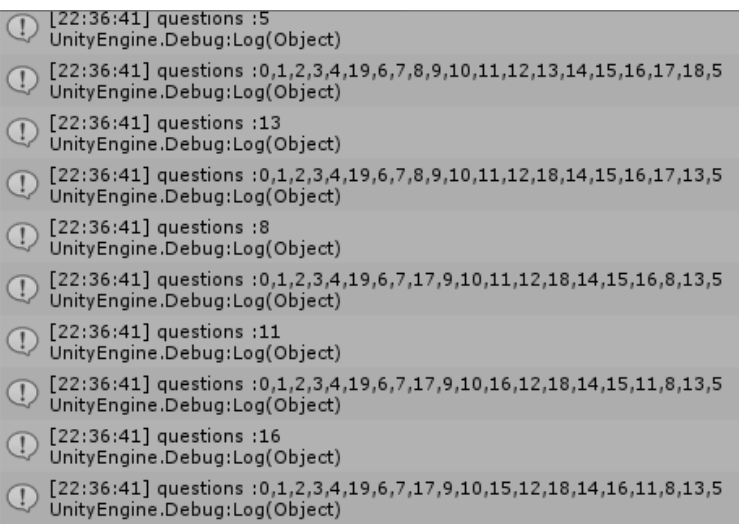

Gambar 3. Proses pengacakan sebelum Fisher-Yates Shuffle

Untuk menentukan index atau elemen keberapa yang akan ditukar dengan index terakhir, digunakan Random.Range library milik unity 3D untuk membangkitkan angka random yang akan dijadikan index untuk ditukar dengan index terakhir. Pada contoh array soal pada gambar 3, index kelima (soal "Manakah yang bukan tempat rekraesi di GWK?") ditukar dengan index ke 19 (index dimulai dari 0 sehingga jumlah soal 20 menjadi 19 index) yaitu "Apa nama gua yang ditinggali Kadru dan anak ularnya?", kemudian index ke 13 (soal "Seberapa jauh jarak pandang patung GWK bisa dilihat?") ditukar dengan index ke 18 (soal "Siapakah nama istri Bhagawan yang terkenal licik?") dan begitu seterusnya hingga elemen terakhir menjadi index ke satu. Hingga perulangan berakhir hasilnya adalah seperti pada gambar berikut :

[22:36:41] questions : $3,4,10,6,2,12,19,9,1,15,18,0,17,14,7,16,11,8,13,5$ UnityEngine.Debug:Log(Object)

Gambar 4. Hasil Acak dengan Random.Range library unity $3 \mathrm{D}$

Seperti pada proses sebelumnya. Index ke 19 setelah proses pengacakan adalah soal "Manakah yang bukan tempat rekraesi di GWK ?", index ke 18 adalah soal "Seberapa jauh jarak pandang patung GWK bisa dilihat?'.Setelah itu untuk melakukan proses penerapan algoritma ke dalam game yang digunakan untuk proses pengacakan digunakan penerapan Random.Range Unity untuk selanjutnya dilakukan penukaran lagi dimana proses algoritma fisher-yates shuffle berhasil diimplementasikan ke dalam game pengacakan.

\subsection{Implementasi Interface}

Implementasi Interface merupakan tampilan dari aplikasi media pembelajaran ini. Pada Implementasi Interface ini di bangun dari perancangan sebelumnya.

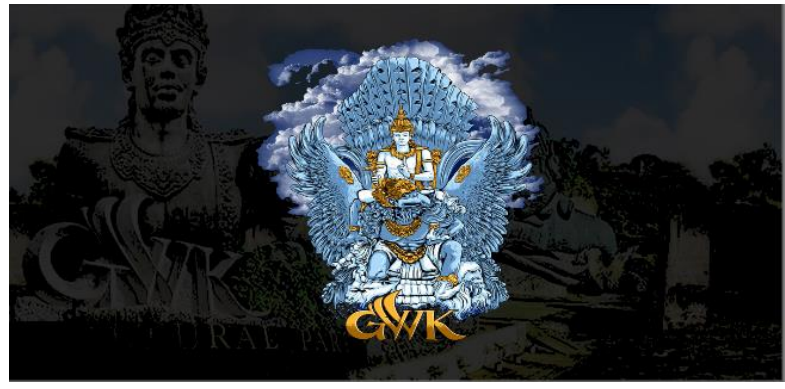

Gambar 5. Splash Screen

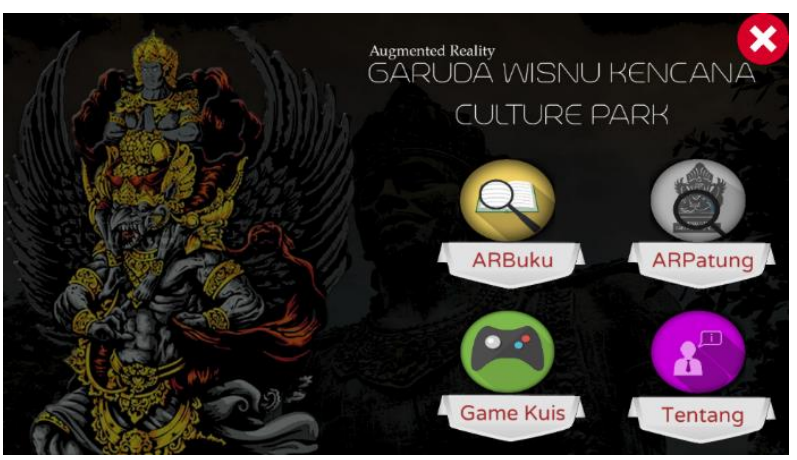

Gambar 6. Halaman Menu Utama

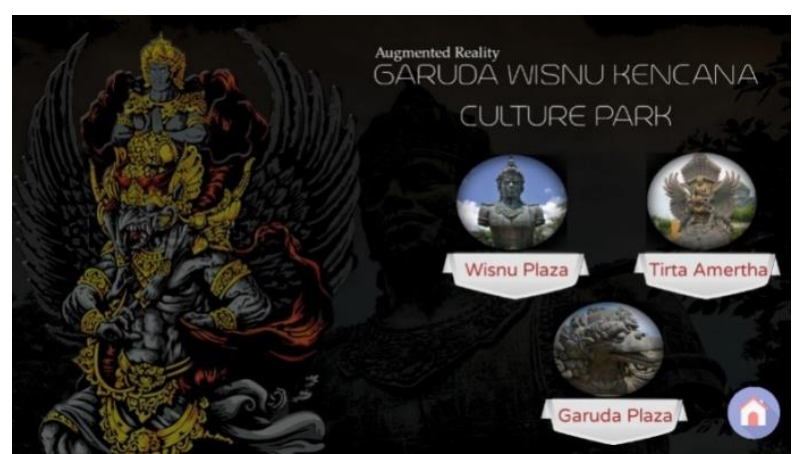

Gambar 7. Menu ARPatung

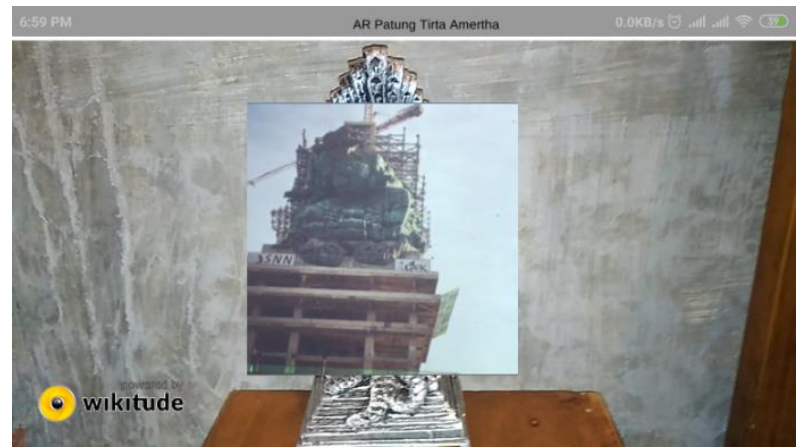

Gambar8. Menu Wisnu Plaza 


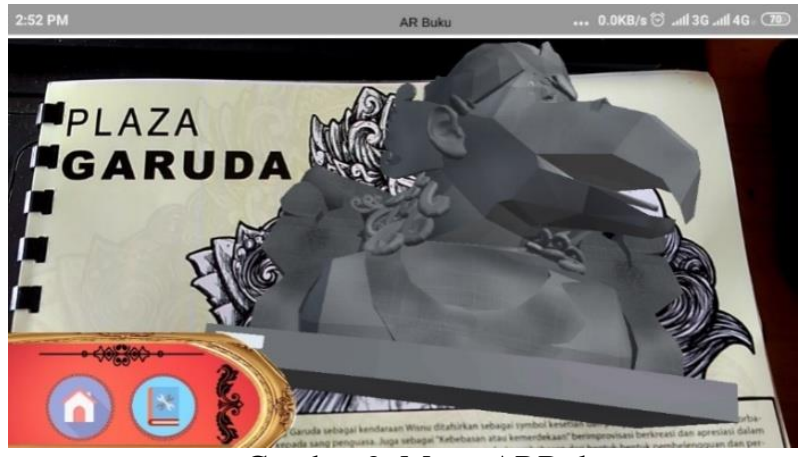

Gambar 9. Menu ARBuku

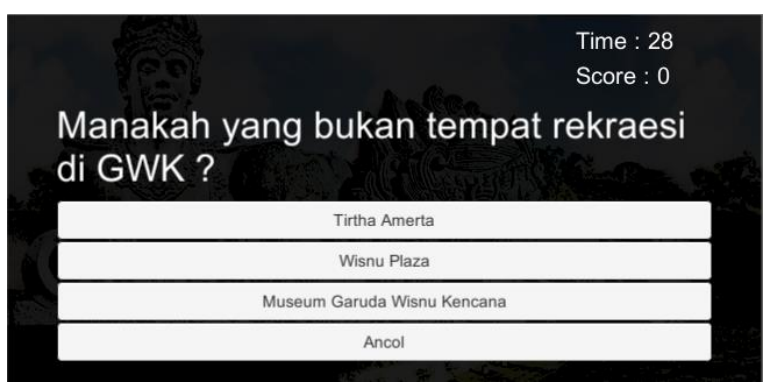

Gambar 10. Menu Kuis

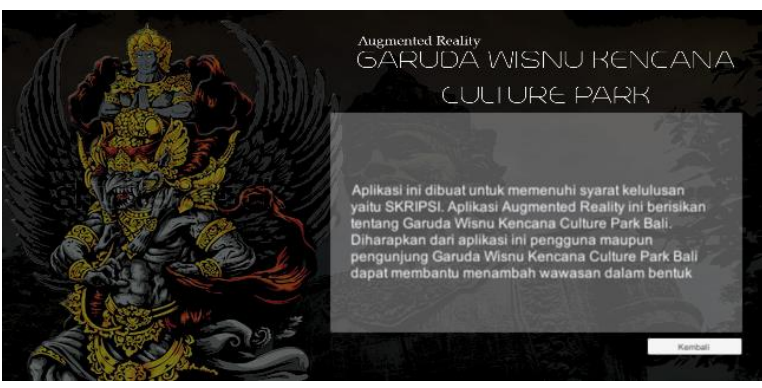

Gambar 11. Menu Tentang

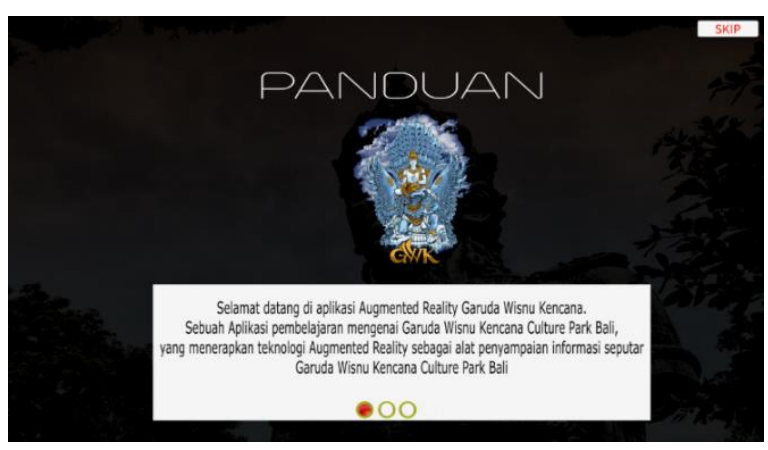

Gambar 12. Menu Panduan

\section{Pembahasan}

Perancangan beserta implementasi telah dilakukan maka selanjutnya perlu dilakukan beberapa pengujian untuk mengetahui cara kerja dari perangkat dan menganalisa tingkat keakuratan, kelemahan serta keterbatasan spesifikasi dari aplikasi dan rangkaian yang telah dibuat. Selain itu pengujian ini juga dilakukan untuk mengetahui tentang bagaimana pengkondisian sistem agar aplikasi ini dapat digunakan dengan optimal.

\subsection{Pengujian Black Box}

Pengujian blackbox merupakan pengujian perangkat lunak yang meniliti fungsi (Functional Testing) dari aplikasi tanpa melihat kedalam struktur internal atau kinerja aplikasi [13]. Dengan adanya pengujian blackbox ini, penulis mengetahui fitur-fitur atau tombol yang tidak bekerja sehingga dapat dilakukan pembaharuan.

\subsection{Pengujian Jarak}

Pengujian jarak ini dilakukan untuk mengetahui fungsionalitas marker ketika dilakukan proses scanning dengan kamera AR. Disini penulis melakukan pengujian pada jarak untuk mengetahui fungsionalitas dari marker agar terdeteksi dengan baik. Di bawah ini hasil dari pengujian jarak:

Tabel 2. Pengujian Jarak ARBuku

\begin{tabular}{cccccc}
\hline Marker & $\begin{array}{c}5 \\
\mathrm{~cm}\end{array}$ & $\begin{array}{c}10 \\
\mathrm{~cm}\end{array}$ & $\begin{array}{c}15 \\
\mathrm{~cm}\end{array}$ & $\begin{array}{c}20 \\
\mathrm{~cm}\end{array}$ & $\begin{array}{c}25 \\
\mathrm{~cm}\end{array}$ \\
\hline $\begin{array}{c}\text { Dewa } \\
\text { Wisnu }\end{array}$ & $\sqrt{ }$ & $\sqrt{ }$ & $\sqrt{ }$ & $\sqrt{ }$ & $\sqrt{ }$ \\
\hline $\begin{array}{c}\text { Tirta } \\
\text { Amertha }\end{array}$ & $\sqrt{ }$ & $\sqrt{ }$ & $\sqrt{ }$ & $\sqrt{ }$ & $\sqrt{ }$ \\
\hline Garuda & $\sqrt{ }$ & $\sqrt{ }$ & $\sqrt{ }$ & $\sqrt{ }$ & $\sqrt{ }$ \\
\hline $\begin{array}{c}\text { Museum } \\
\text { GWK }\end{array}$ & $\sqrt{ }$ & $\sqrt{ }$ & $\sqrt{ }$ & $\sqrt{ }$ & $\sqrt{ }$ \\
\hline $\begin{array}{c}\text { Pintu } \\
\text { Depan }\end{array}$ & $\sqrt{ }$ & $\sqrt{ }$ & $\sqrt{ }$ & $\sqrt{ }$ & $\sqrt{ }$ \\
$\begin{array}{c}\text { Museum } \\
\text { GWK }\end{array}$ & & & & & \\
\hline $\begin{array}{c}\text { Foto }- \\
\text { foto di } \\
\text { dalam } \\
\text { Museum }\end{array}$ & $\sqrt{ }$ & $\sqrt{ }$ & $\sqrt{ }$ & $\sqrt{ }$ & $\sqrt{ }$ \\
\hline
\end{tabular}

Tabel 3. Pengujian Jarak ARPatung

\begin{tabular}{ccc} 
Marker & 2 meter & 4 meter \\
\hline Tirta Amertha & Terdeteksi & Terdeteksi \\
\hline Wisnu Plaza & Tidak Terdeteksi & Terdeteksi \\
\hline Garuda Plaza & Tidak Terdeteksi & Terdeteksi \\
\hline
\end{tabular}

Tabel 2 dan3 diatas menjelaskan hasil pengujian jarak optimal untuk data uji ke-1 sampai data uji ke-15. Kolom yang berisikan nilai "Terdeteksi" maka data uji ke-n pada jarak ke-i mampu terdeteksi oleh aplikasi dan menampilkan object 3D dan video. Sedangkan untuk kolom yang berisikan nilai "Tidak Terdeteksi" menunjukkan bahwa aplikasi ini tidak dapat terdeteksi marker dan menampilkan object 3D dan video.

\subsection{Pengujian Sudut}

Pengujian kemiringan Object 3D digunakan untuk mencari jarak kemiringan terdekat dan kemiringan terjauh yang dibutuhkan aplikasi dalam mengenali marker, menampilkan objek 3D. Pengujian dilakukan dengan mengarahkan perangkat 
android yang telah mengarahkan fitur deteksi marker dengan variasi jarak miring yang ditentukan. Variasi data uji berupa perbedaan jarak miring antara $0^{\circ}-90^{\circ}$ pada setiap data uji.

Tabel 4 Pengujian Sudut

\begin{tabular}{|c|c|c|c|c|c|}
\hline \multirow{2}{*}{ No. } & \multirow{2}{*}{$\begin{array}{l}\text { Data Marker } \\
\text { yang di Scane }\end{array}$} & \multicolumn{4}{|c|}{ Hasil Pengujian kemiringan object 3D } \\
\hline & & $0^{\circ}$ & $30^{\circ}$ & $60^{\circ}$ & $90^{\circ}$ \\
\hline 1. & Dewa Wisnu & $\mathrm{Ya}$ & $\mathrm{Ya}$ & Ya & $\mathrm{Ya}$ \\
\hline 2. & Tirta Amertha & Ya & $\mathrm{Ya}$ & $\mathrm{Ya}$ & Ya \\
\hline 3. & Garuda & $\mathrm{Ya}$ & $\mathrm{Ya}$ & $\mathrm{Ya}$ & $\mathrm{Ya}$ \\
\hline 4. & $\begin{array}{l}\text { Museum } \\
\text { GWK }\end{array}$ & Ya & $\mathrm{Ya}$ & $\mathrm{Ya}$ & $\mathrm{Ya}$ \\
\hline 5. & $\begin{array}{c}\text { Pintu Depan } \\
\text { Museum } \\
\text { GWK }\end{array}$ & $\mathrm{Ya}$ & Ya & Ya & $\mathrm{Ya}$ \\
\hline 6. & $\begin{array}{c}\text { Foto - foto di } \\
\text { dalam } \\
\text { Museum } \\
\end{array}$ & Ya & Ya & Ya & Ya \\
\hline
\end{tabular}

Dari hasil pengujian sudut diatas dapat kita ketahui bahwa marker dapat terdeteksi pada jarak sudut antara $0^{\circ}$ sampai $60^{\circ}$, untuk $90^{\circ}$ marker dapat terdeteksi hanya saja untuk rangkaian makanan tidak dapat terdeteksi dengan baik.

\subsection{Pengujian Sudut}

Pengujian Usability dilakukan untuk mengetahui tingkat kegunaan aplikasi Augmented Reality Garuda Wisnu Kencana. Pengujian dilakukan pada 22 pengguna aplikasi (responden) yang terdiri dari 20 pengguna yang belum pernah ke GWK Culture Park dan 2 pengunjung GWK Culture Park dengan memberikan kuesioner baik secara lisan maupun tertulis. Pengujian ini menggunakan kuisioner yang terdiri dari 10 pertanyaan (contoh dapat dilihat di lampiran). Berikut adalah dokumentasi dari pengujian usability.

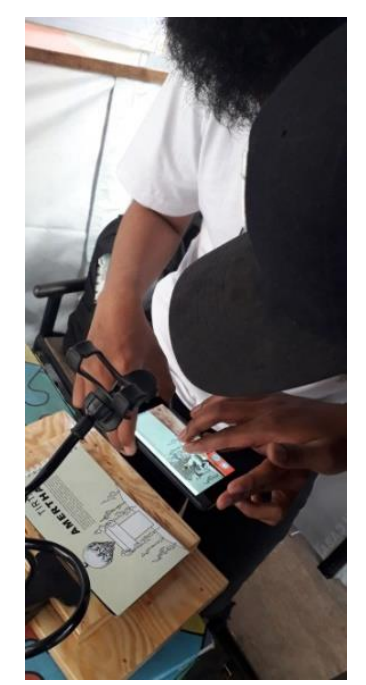

Gambar 13. Pengujian Pada Pengguna
Pada gambar 13 terlihat pengguna melakukan pengujian Scanning dengan marker untuk mengetahui fitur dari aplikasi, dan melakukan scanning marker.

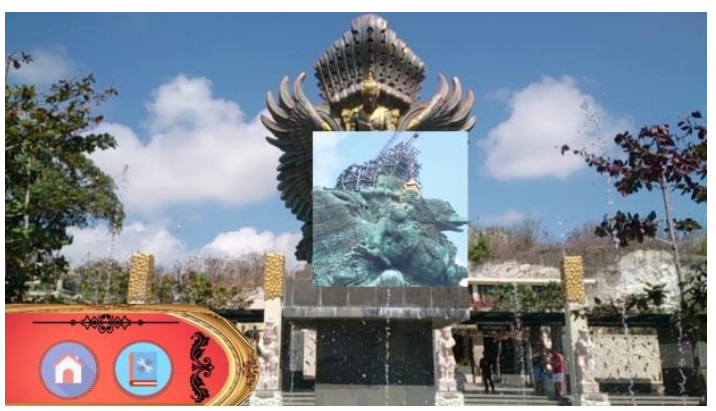

Gambar 14. Pengujian Pada Pengguna

Pada gambar 14 terlihat pengguna melakukan pengujian Scanning dengan marker untuk mengetahui fitur dari aplikasi, dan melakukan scanning marker.

Tabel 5. Skala Pengukuran Kuesioner

\begin{tabular}{cc}
\hline Skor & Kriteria Jawaban \\
\hline 5 & Sangat Setuju (SS) \\
\hline 4 & Setuju (S) \\
\hline 3 & Netral (N) \\
\hline 2 & Tidak Setuju (ST) \\
\hline 1 & Sangat Tidak Setuju (STS) \\
\hline
\end{tabular}

Berdasarkan hasil kuisioner diatas, perhitungan usability dilakukan dengan menghitung presentase jawaban dari pengguna dengan menggunakan rumus(Rahman \& Vitalocca, 2001) :

$$
\frac{\text { skor observasi }}{\text { skor yang di harapkan }} \times 100
$$

Keterangan :

Skor observasi = Hasil skor yang di lakukan Skor yang di harapkan $=$ Total skor terbesar. Setelah dilakukan perhitungan presentase menggunakan rumus diatas, maka didapatkan hasil presentase pada tabel 6 berikut ini :

Tabel 6. Hasil Pengujian Kuesioner

\begin{tabular}{|l|l|c|c|c|}
\hline No. & Pertanyaan & $\begin{array}{c}\text { Skor } \\
\text { Responden }\end{array}$ & $\begin{array}{c}\text { Skor } \\
\text { Maksimal }\end{array}$ & $\begin{array}{c}\text { Presentasi } \\
(\%)\end{array}$ \\
\hline 1. & $\begin{array}{l}\text { Aplikasi } \\
\text { ini mudah } \\
\text { dipahami }\end{array}$ & 99 & 110 & $90 \%$ \\
\hline 2. & $\begin{array}{l}\text { Pengopera } \\
\text { sian scan } \\
\text { mudah } \\
\text { digunakan }\end{array}$ & 102 & 110 & $92.7 \%$ \\
\hline 3. & $\begin{array}{l}\text { Aplikasi } \\
\text { ini mudah } \\
\text { untuk } \\
\text { dipelajari } \\
\text { cara }\end{array}$ & 94 & 110 & $85,4 \%$ \\
\hline
\end{tabular}




\begin{tabular}{|c|c|c|c|c|}
\hline No. & Pertanyaan & $\begin{array}{c}\text { Skor } \\
\text { Responden }\end{array}$ & $\begin{array}{c}\text { Skor } \\
\text { Maksimal }\end{array}$ & $\begin{array}{c}\text { Presentasi } \\
(\%)\end{array}$ \\
\hline & $\begin{array}{l}\text { penggunaa } \\
\text { nnya }\end{array}$ & & & \\
\hline 4. & $\begin{array}{l}\text { Aplikasi } \\
\text { ini } \\
\text { membantu } \\
\text { saya } \\
\text { menjadi } \\
\text { lebih } \\
\text { efektif }\end{array}$ & 87 & 110 & $79 \%$ \\
\hline 5. & $\begin{array}{l}\text { Saya dapat } \\
\text { mengguna } \\
\text { kan } \\
\text { aplikasi ini } \\
\text { tanpa } \\
\text { instruksi } \\
\text { tertulis }\end{array}$ & 89 & 110 & $81 \%$ \\
\hline 6. & $\begin{array}{l}\text { Aplikasi } \\
\text { ini } \\
\text { menampilk } \\
\text { an } 3 \\
\text { Dimensi } \\
\text { patung }\end{array}$ & 105 & 110 & $95,4 \%$ \\
\hline 7. & $\begin{array}{l}\text { Aplikasi } \\
\text { ini nyaman } \\
\text { untuk } \\
\text { digunakan }\end{array}$ & 93 & 110 & $84,5 \%$ \\
\hline 8. & $\begin{array}{l}\text { Tampilan } \\
\text { user } \\
\text { interface } \\
\text { aplikasi } \\
\text { sudah } \\
\text { menarik } \\
\text { dan mudah } \\
\text { dipahami } \\
\end{array}$ & 98 & 110 & $89 \%$ \\
\hline 9. & $\begin{array}{l}\text { Soal dan } \\
\text { jawaban } \\
\text { kuis dapat } \\
\text { terbaca } \\
\text { dengan } \\
\text { jelas }\end{array}$ & 94 & 110 & $85,4 \%$ \\
\hline 10. & $\begin{array}{l}\text { Aplikasi } \\
\text { ini } \\
\text { menghema } \\
\text { t waktu } \\
\text { saya ketika } \\
\text { mengguna } \\
\text { kannya }\end{array}$ & 89 & 110 & $81 \%$ \\
\hline & Total & 950 & 1100 & $86,3 \%$ \\
\hline
\end{tabular}

Tabel 7. Ketertarikan

\begin{tabular}{cc}
\hline Angka (\%) & Klasifikasi \\
\hline$<21$ & Sangat Tidak Layak \\
\hline $21-40$ & Tidak Layak \\
\hline $41-60$ & Cukup \\
\hline $61-80$ & Layak \\
\hline $81-100$ & Sangat Layak \\
\hline
\end{tabular}

Pengujian usability dilakukan untuk mencoba mengaplikasikan aplikasi media pembelajaran yang telah di buat, serta mengetahui penilaian pengguna terhadap aplikasi media pembelajaran ini berdasarkan kuisioner yang telah di bagikan. Dan hasil dari pengujian Usability dengan kuisioner ini menyatakan bahwa aplikasi Media Pembelajaran Interaktif Terhadap GWK Culture Park Menggunakan Teknologi Augmented Reality Sangat menarik untuk digunakan dengan presentase sebesar $86.3 \%$

\section{Pembahasan \\ 6.1 Kesimpulan}

Berdasarkan dari hasil analisis, perancangan, implementasi serta pengujian yang telah dilakukan maka dapatdiambil kesimpulan sebagai berikut:

a. Aplikasi Augmented Reality Garuda Wisnu Kencana sesuai dengan analisis kebutuhan yaitu dapat memberikan pembelajaran menggunakan teknologi tanpa pembelajaran secara manual. Dan user dapat belajar dengan mudah dimanapun berada, memiliki kreativitas dan daya nalar dalam melakukan proses pembelajaran.

b. Berdasarkan pengujian usability melalui kuisioner yang telah diberikan kepada pengguna aplikasi dapat diperoleh hasil kepuasan dalam memberi tanggapan yang sangat baik untuk melakukan proses pembelajaran secara mudah dan efisien.

c. Dari hasil implementasi dan uji coba yang dilakukan oleh peneliti, dapat menarik kesimpulan bahwa metode Fisher Yates Shuffle dapat diaplikasikan untuk pengacakan pertanyaan pada sebuah game dengan baik dan optimal. Pertanyaan dimasukkan kedalam sebuah arraylist dengan panjang $20 \quad(\mathrm{~N}=20)$ kemudian dilakukan pengacakan pada perulangan dan pengacakan. Ini membuktikan bahwa hasil pengacakan telah berjalan.

\subsection{Saran}

Dalam pembuatan game ini masih terdapat banyak kekurangan yang perlu dilakukan perbaikan dan pengembangan untuk menjadikan aplikasi ini menjadi semakin bagus dan diminati banyak orang, oleh karena itu penulis menyarankan beberapa hal untuk bahan pengembangan selanjutnya, diantaranya:

a. Mengambangkan aplikasi ini agar memiliki tampilan yang lebih menarik lagi.

b. Adanya pengemangan multiplatform agar dapat dimainkan diberbagai sistem operasi mobile tidak hanya android.

c. Menambah bank pertanyaan dan pilihan tema pertanyaan.

d. Menjadikan fitur AR Patung bisa diakses tanpa harus ke lokasi 


\section{Dafar Pustaka:}

[1] Lutfiyati, T.A. (2016). Aplikasi Augmented Reality Pembelajaran Pengenalan Hardware Komputer Untuk Sekolah Menengah Pertama Dengan Metode Transformasi Geometri (Thesis). Jurusan Teknik Informatika, Fakultas Sains dan Teknologi, Universitas Islam Negeri Maulana Malik Ibrahim, Malang

[2] Putra, E.Y, Wahyudi, AK Perancangan Perangkat Visualisasi Interaktif Situs Warisan Budaya Indonesia Menggunakan Teknologi Augmented Reality Dengan Metode Simultaneous Markerless Based Manado(ID): Universitas Klabat, 2015.

[3] Ekojono, Irawati, D.A, Affandi, L., Rahmanto, A.N, Penerapan Algoritma Fisher-Yates Pada Pengacakan Soal Game Aritmatika, 9: 20852347, 2017 